\title{
Yenidoğanda Hipotansiyon ve Tedavisi
}

\author{
Hypotension in Newborn Infants and Its Treatment
}

Nilay Hakan, Mustafa Aydın

Dr. Sami Ulus Kadın Doğum, Çocuk Sağlı̆ı ve Hastalıklanı Eğitim ve Araştırma Hastanesi, Yenidoğan Kliniği, Ankara, Türkiye

Yazısma Adresi/Address for Correspondence Dr. Nilay Hakan, Dr. Sami Ulus Kadın Doğum, Çocuk Sağlı̆̆ı ve Hastallkları Eğitim ve Araștırma Hastanesi, Yenidoğan Kliniği, Ankara, Türkiye Tel.: +904422325555 E-posta: nilayhakan1@gmail.com

Geliş Tarihi/Received: 20.12.2012 Kabul Tarihi/Accepted: 12.03.2013

(c) Güncel Pediatri Dergisi, Galenos Yayınevi tarafindan basilmıştr.

(c) The Journal of Current Pediatrics, published by Galenos Publishing.

\section{ÖZET}

Sistemik hipotansiyon hasta prematüre bebeklerde sık görülen bir komplikasyon olup ventrikül içi kanamayı, nörogelişimsel morbiditeyi ve mortaliteyi de içeren bazı olumsuz sonuçlara neden olabilir. Neonatologlar arasında hem hipotansiyonun tanımı hem de nörolojik hasara neden olabilen sistemik arteriyel kan basıncı alt sınıı değeri bakımından bir fikir birliği yoktur. Bu nedenle bildirilen hipotansiyon prevalansları yenidoğan üniteleri arasında değişkenlik gösterir. Bununla birlikte, klinisyenlerin çoğu tarafından yenidoğanda nörolojik sonuçları ve yaşam oranlarını iyileştirdiği düşünülerek hipotansiyonun erken ve etkin tedavisi kabul görmüştür. Hipotansiyon tedavisinde amaç yeterli organ kan akımını, özellikle serebral kan akımını sağlamaktır. Tedavi kararı, serebral oksijen dağılımının yeterliliği ve organ perfüzyonunun değerlendirilmesindeki zorluklardan dolayı, klinik öngörü ile beraber gestasyonel ve postnatal yaşa göre belirlenmiş normal kan basıncı değerlerine göre verilmektedir. Günümüzde prematüre bebeklerde hipotansiyon tedavisinde hacim genişleticiler, inotrop, vazopressör ajanlar ve kortikosteroidler kullanılmaktadır. Yenidoğanda yaygın olarak kullanılan inotropik ajanlardan dopaminin kan basıncını arttırmada dobutaminden daha etkili olduğu bildirilmiştir. Bazı hipotansif prematüre bebeklerde adrenokortikal yetmezlik nedeniyle kortizol düzeyleri düşüktür ve kortikosteroidler genel olarak bu bebeklerde dirençli hipotansiyon tedavisi için bekletilir; bununla birlikte potansiyel yan etkileri nedeniyle profilaktik ya da rutin klinik kullanımı önerilmez. Bu yazıda yenidoğanda sistemik hipotansiyonun tanı ve tedavisi ile ilgili bazı tartışmalı noktalar gözden geçirilecektirr. (Güncel Pediatri 2013; 11: 68-76)

Anahtar kelimeler: Yenidoğan, hipotansiyon, tedavi, damar büzücü ajanlar

\section{SUMMARY}

Systemic hypotension is a common complication of sick premature infants and may be associated with major adverse outcomes, including intraventricular hemorrhage, neurodevelopmental morbidity, and mortality. There is no consensus among neonatologists regarding either the definition of hypotension or the lower threshold level of systemic arterial blood pressure in which neurological injury is inevitable. For this reason, there is a considerable variation in the reported prevalence of hypotension among different neonatal units. However, it is widely accepted by many of clinicians that early and aggressive treatment of hypotension in the neonates leads to improved neurologic outcome and survival. The goal of treatment of hypotension is to maintain adequate organ blood flow, particularly, cerebral blood flow. Because of difficulties in evaluating organ perfusion and adequacy of cerebral oxygen delivery, treatment decisions are based on statistically defined gestational and postnatal agedependent normative blood-pressure values combined with clinical intuition. Current treatment of hypotension in the premature infant includes the use of volume expansions, inotropes, vasopressor agents and corticosteroids. It has been reported that dopamine, as a commonly used inotropic agents in the neonatal period, is more effective than dobutamine in the raising of blood pressure. Some hypotensive premature infants have low cortisol levels because of adrenocortical insufficiency, and corticosteroids are generally reserved for treatment of refractory hypotension of these infants; however, it is not recommended for prophylaxis or routine clinical use because of its potential serious side effects. This article aims to review some of the controversies about diagnosis and management of systemic hypotension in the newborn infants. (Journal of Current Pediatrics 2013; 11: 68-76)

Key words: Newborn infant, hypotension, treatment, vasoconstrictor agents 


\section{Giriș}

Arteriyel kan basıncı, kardiyak atım hacmi ve periferik damar direnci tarafından belirlenir. Genel olarak hipotansiyon, yetersiz sistemik kan akımını veya yetersiz sol ventrikül atım hacmini ve bunun sonucunda gelişen yetersiz doku perfüzyonunu gösterir. Kan basıncındaki düşme kan akımının azalmasına ve belirli değerlerin altında ise organ perfüzyon bozukluğuna ve doku hipoksisine neden olur. Hipotansiyonun tanı ve tedavisi özellikle yenidoğan bebeklerde gelişebilecek serebral iskemik hasar, periventriküler lökomalazi (PVL) ve ventrikül içi kanama (VIK) gibi komplikasyonlardan kaçınmak için önemlidir (1,2). Sistemik hipotansiyon uzun dönemde prematüre bebeklerde nörogelişimsel morbiditeye neden olabilir, zamanında doğmuș bebeklerdeki etkilerine dair ise çok az bilgi vardır (3).

Bu yazının amacı yenidoğanda sistemik hipotansiyonun tanı ve tedavisindeki bazı tartışmalı noktaları gözden geçirmektir.

\section{Sıklık}

Neonatologlar arasında sistemik arteriyel kan basıncı alt sınıı değerleri bakımından herhangi bir fikir birliği olmadığından dolayı değișik üniteler arasında çok farklı sıklıklar bildirilmektedir. Yenidoğan yoğun bakım ünitelerine yatırılan bebeklerin yatışlarının ilk gününde dört ya da beşte birinde hipotansiyon olduğu bildirilmektedir (4). Hipotansiyon sıklığı özellikle çok düșük doğum ağırlıklı (ÇDDA) prematüre bebeklerde kısmen daha yüksektir. ÇDDA bebeklerin yaklaşık üçte birinde sistemik hipotansiyon tanısı konulmuştur (5).

\section{Patofizyoloji}

Hipotansiyon ve şokun başlangıcında çok sayıda kompansatuvar mekanizma (arteriolar damarlarda kasılma, kalp hızı ve kardiyak atım hacminde artma, antidiüretik ve vazoaktif hormonların salınması) devreye girer. Bu kompansatuvar mekanizmalar, sistemik oksijen dağılımının en hayati organlara (beyin, kalp ve adrenal bezler) yönlendirilmesini sağlar. Bunun sonucunda böbreklerin, gastrointestinal sistem organlarının ve derinin perfüzyonu azalır (6).

\section{Hipotansiyonun Nedenleri}

Yenidoğanlarda hipotansiyonun pek çok nedeni vardır $(7,8)$, (Tablo 1). Miadında doğmuş yenidoğanlarda hipotansiyonun belirlenmesi hipovolemik şok, sistemik enflamatuvar yanıt sendromu, kardiyak işlev bozuklukları (obstrüktif sol kalp lezyonları, miyokard hastalıkları, koroner arter anomalileri), pulmoner hava kaçağı, perikard efüzyonu, metabolik ve endokrin bozuklukları (hipoglisemi, adrenal yetmezlik) akla getirir. Zamanında doğmuş bebeklerde hipotansiyona neden olan durumlar prematürelerde de hipotansiyona yol açabildiği gibi, bu grupta hipotansiyonun başlıca nedenleri anormal periferik vazoregülasyon ve miyokard fonksiyon bozukluğudur. Kan hacmi ve basıncı arasındaki ilişkinin zayıflığı ve dopaminin kan basıncını yükseltmede hacim yüklemesine göre daha etkili olması, prematürelerdeki hipotansiyonda hipovoleminin rolünün daha az olduğunun önemli göstergeleridir (9). Buna karşın, fazla idrar çıkaran, aşırı transepidermal sıvı ve akut kan kaybı bulguları olan bir prematüre bebekte hipotansiyonun başlıca nedeni hipovolemi kabul edilerek tedavi ona göre planlanmalıdır. Ciddi asfiktik prematüre bebeklerde hipotansiyonun gelişmesinde miyokard fonksiyon bozukluğu ası nedendir. Asfiktik bebeklerde ayrıca hipovolemi ve anormal vasküler tonus da hipotansiyona neden olabilir (10).

\section{Klinik Bulgular}

Öyküde hastada risk faktörlerinin olup olmadığı sorgulanır. Uzamış kapiller dolum zamanı, taşikardi, kutis marmoratus, soğuk ekstremiteler ve oligüri hipotansiyon ile birlikte şokun önemli fizik muayene bulgulardır. Santral ve periferik vücut ISISI arasındaki fark hipovolemi ve sepsisin bir bulgusu olabilir. Solunum sesleri ve kalp sesleri dikkatlice dinlenmeli, periferik nabızlar muayene edilmelidir (11).

\section{Hipotansiyon Tanısı}

Klinikte özgül organ kan akımını ölçmek oldukça zordur. Kan basıncı dokuların perfüzyonunu tam olarak yansıtmadığı halde günlük pratikte sistemik dolaşımın yeterliliğini ölçmek için bir alternatiftir $(4,8)$.

ÇDDA olan bebeklere özgü kan basıncı değerlerinin belirlenmesine ilişkin cevaplanmamış pek çok soru mevcuttur. Bu nedenle özellikle 28 hafta altında doğan prematüre bebeklerde hipotansiyonun tanımlanması güçlük taşımaktadır. Bununla birlikte, zamanında ve 2836 haftalar arasında prematüre doğmuş sağlık sorunu olmayan yenidoğanlarda kan basıncı değerleri için tanımlayıcı veriler bulunmaktadır. Sistemik kan basıncı normal değerleri gestasyonel yaşa, doğum ağırlığı ve postnatal yaşa göre değişiklik gösterir ve bu değişkenler küçüldükçe ortalama kan basıncı değerleri azalır (12-14). Hipotansiyon, ortalama kan basıncının bebeğin doğum ağırlı̆̆ı ve gestasyon yaşına özgü referans değerlerinin 5 . veya 10. persentilin altında olması olarak tanımlanabilir. Pratik uygulamada, genel olarak, hipotansiyonu tanımlamada iki parametre kullanılmaktadır. Bunlar yaşamın ilk üç günü ortalama kan basıncı alt sınırının 
pratik olarak bebeğin gestasyon haftasının altında olması ya da $30 \mathrm{mmHg}$ 'dan düşük olmasıdır. 3. günden sonra ise 23-26 haftalık bebeklerin \%90'nında ortalama kan basıncı 30 mmHg'nın üzerindedir (12). Tablo 2 ve Şekil 1'de 1500 $g$ ve altında doğan bebeklerin ortalama kan basıncı 10. ve 50. persentil değerleri verilmiştir $(1,7)$.

\begin{tabular}{|c|}
\hline Hipovolemi \\
\hline Plasental kanama, plasenta previa, ablasyo plasenta \\
\hline Umblikal kord yaralanmaları \\
\hline Feto-maternal kanama \\
\hline İkizden ikize kanama \\
\hline Doğum travması, kanama \\
\hline Karaciğer/dalak rüptürü \\
\hline Masif pulmoner kanama \\
\hline Yaygın damar içi pıntılaşması \\
\hline $\begin{array}{l}\text { Üçüncü boşluklara kayıp- intrakranial, intrabdominal, subgaleal } \\
\text { kanamalar }\end{array}$ \\
\hline $\begin{array}{l}\text { Fetal-neonatal hemoliz: kan grubu uygunsuzlukları, eritrosit } \\
\text { membran ve enzim defektleri }\end{array}$ \\
\hline Kardiyak nedenler \\
\hline Intrauterin ve/veya intrapartum asfiksi \\
\hline $\begin{array}{l}\text { Aritmiler (supraventriküler taşikardi, ventriküler taşikardi, } \\
\text { fibrilasyon, uzun QT sendromu) }\end{array}$ \\
\hline Konjenital kalp hastalıkları \\
\hline $\begin{array}{l}\text { Hipoplastik sol kalp, kritik aort stenozu, PDA*, total anorr } \\
\text { dönüş, vb. }\end{array}$ \\
\hline Kardiyomiyopati \\
\hline Miyokardit \\
\hline Perikard tamponadı \\
\hline Kardiyotoksik ilaçlar \\
\hline Pulmoner nedenler \\
\hline Pulmoner hava kaçağı sendromları (pnömotoraks) \\
\hline $\begin{array}{l}\text { Yüksek basınçlı pozitif ventilasyon ile akciğerlerin aşırı } \\
\text { distansiyonu }\end{array}$ \\
\hline Diyafragma hernisi \\
\hline Sepsis ve septik şok \\
\hline Endokrin nedenler \\
\hline Adrenogenital sendrom \\
\hline Adrenal kanama \\
\hline Maternal anestezi/hipotansiyon \\
\hline Illaçlara bağı hipotansiyon \\
\hline
\end{tabular}

\section{Hipotansiyonun Önemi}

Özellikle ÇDDA olan bebeklerde hipotansiyon ve tedavisi tartışıırken bebeğin mevcut tanısı, fetal dolaşımdan postnatal dolaşıma geçiş, postnatal yaşamın ilk birkaç günü boyunca foramen ovale ve duktustan oluşan şantların varlığı, sistemik vazokonstriksiyon ve ayrıca sistemik ve serebral hemodinamiler arasındaki etkileşim önemlidir (15). Örneğin postnatal yaşamın ilk 6-12 saati boyunca bazı ÇDDA olan bebeklerde sistemik kan akımı düşüktür ve herhangi bir soruna neden olmaz (16). Bu dönemde sistemik kan akımının düşük olmasının nedeni umblikal kordun klemplenmesinin ve düşük dirençli plasentanın uzaklaştııımasının ardından sistemik vasküler direncin ani olarak artması ve buna bağlı immatür miyokardın pompa yeteneğinin azalmasıdır (17). Postnatal yaşamın 36. saatinden sonra ise düşük olan sistemik kan akımı normal düzeye döner (18).

ÇDDA olan bebeklerde doğumda serebral vaskülarizasyon tamamlanmamıştır ve doğumda strese cevap olarak ön beyin damarlarında önce vazokonstriksiyon ardından vazodilatasyon gelişir. Bu nedenle normal kabul edilen sistemik kan basıncı değerlerinde bile serebral kan akımı düşük olabilir (19). Gerçekten de prematüre bebeklerde serebral perfüzyon doğumu izleyen günlerden

$\begin{aligned} & \text { Tablo 2. Doğum ağırlığına göre ortalama kan basıncı } 10 . \\
& \text { persentil değerleri }(\mathbf{1 , 7 )}\end{aligned}$
\begin{tabular}{|l|l|}
\hline Doğum ağılığı $(\mathrm{g})$ & $\begin{array}{l}\text { Ortalama kan basıncı } \\
\text { 10. persentil değerleri } \\
(\mathrm{mmHg})\end{array}$ \\
\hline $500-750$ & 26 \\
\hline $750-1000$ & 28 \\
\hline $1000-1250$ & 29 \\
\hline $1250-1500$ & 30 \\
\hline
\end{tabular}

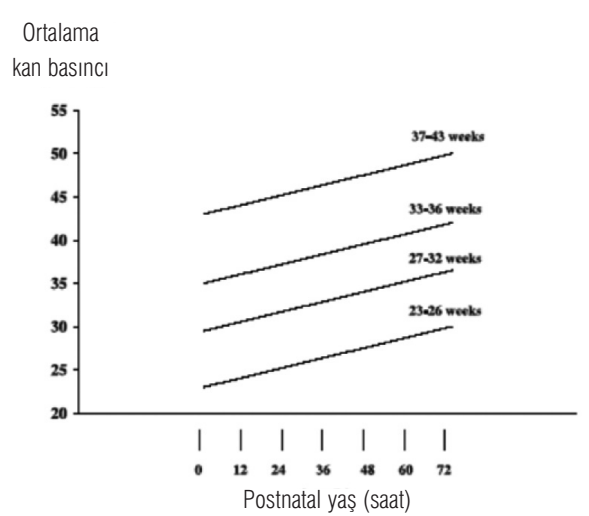

Şekil 1. Doğum ağırlığı 1500 g'ın altında olan bebeklerde ilk hafta içinde gestasyonel ve postnatal yaşa göre ortalama kan basıncının 50. persentil eğrileri $(1,7)$ 


\begin{tabular}{|c|c|c|c|c|}
\hline Illaç & Kategori & Etki mekanizması & Hemodinamik etkisi & Dozu \\
\hline Epinefrin & Inotrop/vazopressör & $\alpha$ ve $\beta$ adrenerjik agonist & $\begin{array}{l}\text { Miyokard kontraktilitesinde ve } \\
\text { kardiyak atımda artış, periferik } \\
\text { vazokonstrüksiyon }\end{array}$ & $\begin{array}{l}\text { Intravenöz infüzyon } \\
0,05-2,5 \mu \mathrm{g} / \mathrm{kg} / \mathrm{dk}\end{array}$ \\
\hline Norepinefrin & Vazopressör & $\alpha$ ve $\beta$ adrenerjik agonist & Periferik vazokonstrüksiyon & $\begin{array}{l}\text { Intravenöz infüzyon } \\
0,1-1,5 \mu \mathrm{g} / \mathrm{kg} / \mathrm{dk}\end{array}$ \\
\hline Dopamin & Inotrop/vazopressör & $\alpha$ ve $\beta$ adrenerjik agonist & $\begin{array}{l}\text { Periferik vazokonstrüksiyon, miyokard } \\
\text { kontraktilitesinde ve kardiyak atımda } \\
\text { artış }\end{array}$ & $\begin{array}{l}\text { Intravenöz infüzyon } \\
2,5-20 \mu \mathrm{g} / \mathrm{kg} / \mathrm{dk}\end{array}$ \\
\hline Dobutamin & Inotrop & $\beta$ adrenerjik agonist & $\begin{array}{l}\text { Miyokard kontraktilitesi ve kardiyak } \\
\text { atımda artış }\end{array}$ & $\begin{array}{l}\text { Intravenöz infüzyon } \\
5-20 \mu \mathrm{g} / \mathrm{kg} / \mathrm{dk}\end{array}$ \\
\hline Dopeksamin & Inotrop & $\beta$ adrenerjik agonist & $\begin{array}{l}\text { Miyokard kontraktilitesi ve kardiyak } \\
\text { atımda artış }\end{array}$ & $\begin{array}{l}\text { Intravenöz infüzyon } \\
2 \mu \mathrm{g} / \mathrm{kg} / \mathrm{dk}\end{array}$ \\
\hline Metilen mavisi & $\begin{array}{l}\text { Çözünebilir guanilat } \\
\text { siklaz inhibitörü }\end{array}$ & $\begin{array}{l}\text { cGMP /Nitrik oksit yolu } \\
\text { inhibisyonu }\end{array}$ & Periferik vazokonstrüksiyon & $\begin{array}{l}\text { Intravenöz infüzyon } \\
1 \mathrm{mg} / \mathrm{kg}, 1 \text { saat }\end{array}$ \\
\hline Hidrokortizon & Kortikosteroid & $\begin{array}{l}\text { Dolaşımdaki } \\
\text { katekolaminlerin duyarılıı̆ını } \\
\text { arttıır }\end{array}$ & Kesin değil & $\begin{array}{l}\text { Intravenöz puşe } \\
2-6 \mathrm{mg} / \mathrm{kg} / \text { gün, 2-6 } \\
\text { doz }\end{array}$ \\
\hline $\begin{array}{l}\text { Hacim genişleticiler } \\
\text { (örn. \%0,9 sodyum } \\
\text { klorür, \%4,5 insan } \\
\text { albümini) }\end{array}$ & Hacim genişletici & $\begin{array}{l}\text { Damar içi hacmi artırma, } \\
\text { Frank-Starling mekanizması }\end{array}$ & Kardiyak atımda artış & $\begin{array}{l}\text { Intravenöz infüzyon } \\
10-20 \mathrm{ml} / \mathrm{kg}, 30 \mathrm{dk}\end{array}$ \\
\hline
\end{tabular}

$\alpha$ : alfa; $\beta$ : beta; cGMP: döngüsel guanosin monofosfat

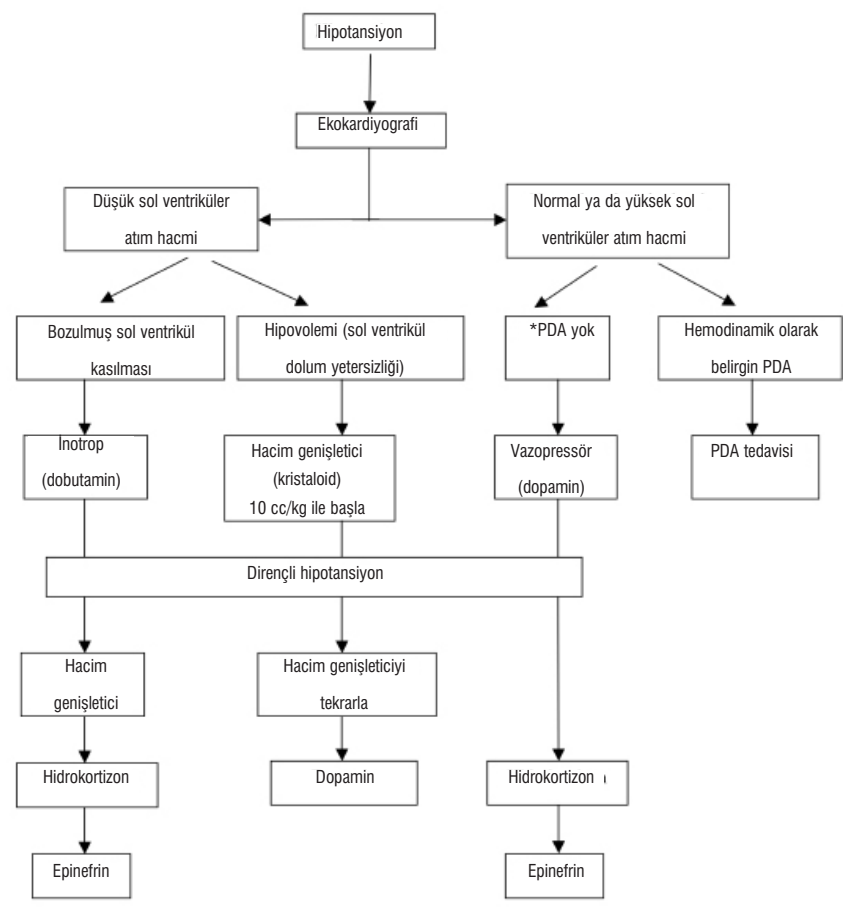

Şekil 2. Ekokardiyografik bulgular temelinde yenidoğanda hipotansiyon tedavi algoritması (26) *:patent duktus arteriozus 
vitibaren 34. gestasyonel haftaya ulaşıncaya kadar giderek $\operatorname{artar}(20)$.

Hipotansiyon ve serebral lezyon gelişimi arasındaki ilişki net değildir. Bazı çalışmalarda serebral kan akımı ve sistemik arteriyel ortalama kan basıncı arasında bir ilişki olmadığı gösterilmiş, yenidoğanlarda serebral kan akımı otoregülasyon mekanizmasının korunduğu ve kan basıncının tek başına nörogelişimsel morbiditeden sorumlu olmayabileceği ileri sürülmüştür (21). Başka çalışmalarda ise yaşamın ilk birkaç gününde ortaya çıkan hipotansiyonun VIK ve/veya PVL riskini belirgin oranda arttırdığı bildirilmiştir (1).

Hipotansiyonun süresi ve şiddeti de nörogelişimsel prognozda önemlidir (3). Goldstein ve ark. (22) yaptıkları bir çalışmada, hipotansiyonun süresinin uzaması ile nörogelişimsel geriliğin arttığını göstermişlerdir. Başka bir çalışmada hipotansiyonun ağırlığı ile Bayley psikomotor gelişim indeksi skorları ve dil gelişimi arasındaki ilişkiye bakılmış ve ağır derecede hipotansiyonu olan prematüre bebeklerin psikomotor ve dil gelişimlerinin geri olduğu bildirilmiştir (23).

\section{Tedavi}

Hipotansiyonun erken tanı ve tedavisi sistemik kan akımını sağlamak, başta serebral kan akımı olmak üzere organ perfüzyonu ve dokulara oksijen sunumu açısından önemlidir (15). Yenidoğan döneminde tedavi kararı, bazı güçlüklere karşın, hemodinamik yetersizliği gösterilmiş, klinik olarak da organ perfüzyon bozukluğu belirtileri gösteren hastalarda daha kolaydır. Permisif hipotansiyonu olan (ortalama arteriyel kan basıncı kabul edilen sınırların altında olmasına karşın hemodinamik bozukluğu olmayan ve klinik belirti göstermeyen) prematüre bebeklerin tedavisi ile küçük prematüre bebeklerin hipotansiyonuna yönelik profilaktik tedavi tartışmalıdır (24). Ahn ve ark. (25) permisif hipotansiyonu olup tıbbi tedavi verilmeyen ÇDDA olan bebekler ile normotansif ÇDDA olan bebekleri 2 yaşında nörogelişimsel açıdan karşılaştırmış ve aralarında bir fark saptamadıklarını bildirmiş̧erdir. Bu çalışmanın sonucunda permisif hipotansiyona sahip ÇDDA olan bebeklerde gereksiz tıbbi tedavilerden kaçınılması gerektiği belirtilmiştir.

Son yıllarda yayınlanan bir kılavuzda ÇDDA olan bebeklerde hipotansiyon tedavisine başlama kararı verirken organ perfüzyonu azalmasının indirekt klinik bulguları olan idrar çıkışındaki değişiklik, metabolik asidoz (yüksek serum laktat düzeyi), yüksek kalp atım hızı ve uzamış kapiller dolum zamanının göz önüne alınması gerektiği bildirilmiştir (15).

Tedavi planı yaparken etyolojide rol oynayan faktörler göz önüne alınmalıdır. Uygulanan tedavi yaklaşımları içinde hacim genişleticiler, dopamin, dobutamin, adrenalin ve kortikosteroid ilaçlar bulunmaktadır (15). Yenidoğanın hipotansiyon tedavisinde kullanılan ilaçlar hakkındaki farmakolojik bilgiler Tablo 3'te özetlenmiştir (26). Sistemik hipotansiyon tedavisinin kısa ya da uzun dönem olumlu nörolojik sonuçlara yol açtığına dair yeterli veri yoktur (27). Pellicer ve ark. (3) yaptıkları bir çalışmada erken dönemde (yaşamın <24 saat) hipotansiyona sahip ÇDDA olan bebeklere inotropik destek tedavisi vermişler. Bu bebekleri 2-3 yaş arasında nörogelişimsel gerilik, serebral palsi ve mortalite açısından hemodinamik olarak stabil olan bebekler ile karşılaştırmış ve iki grup arasında bir fark bulmadıklarını bildirmişlerdir. Düşük sistemik kan basıncını tedavi ile normal aralığa yükseltmenin nörogelişimsel sonuçları düzeltip düzeltemeyeceği konusunda kapsamlı çalışmalara intiyaç vardır.

\section{A. Hacim Genișleticiler}

Yenidoğanlarda hipotansiyon genellikle otonomik immatürite nedeniyle periferik vazoregülasyonun bozulması ve immatür miyokardın disfonksiyonu sonucu oluşur (9). Hipovolemi, özellikle prematüre bebeklerde hipotansiyon gelişiminde ikincil öneme sahiptir. Buna rağmen tedavide sıklıkla ilk basamak olarak hacim genişleticiler kullanıır (28). Kan basıncını arttırmada dopaminden daha az etkilidir (29-31). Küçük prematüre bebeklerde yüksek miktarda hacim genişletici kullanımı pulmoner, kardiyovasküler, gastrointestinal ve santral sinir sistemi morbiditesini arttırabilir (30-32).

Hipoalbuminemi veya kan kaybı yoksa hacim genişletici olarak $10-20 \mathrm{cc} / \mathrm{kg}$ dozunda serum fizyolojik (\%0,9 NaCl) tercih edilmelidir. Bunun nedeni \%0,9 NaCl'nin kan basıncını yükseltici etkisinin \%5 albümin kadar iyi olması, daha az sIVı retansiyonuna yol açması ve daha az pulmoner yan etkiler oluşturmamasıdır (31). Intravasküler SIVI hacmi hidrostatik ve onkotik basınç arasındaki dengeye ve kapiller endotelin geçirgenliğine bağılıdr. Hasta prematürelerde kapiller kaçak sendromuna bağlı olarak damar içi alandan interstisyuma sIvı ve plazma proteini geçişi olur. Hacim genişletici olarak \%5 albümin kullanılan hastalarda erken dönemde ödem daha fazla görülmüştür. Hastanın kan basıncı normal düzeylere dönüp, idrar çıkarmaya başlayınca ve eğer devam eden bir sıvı kaybı da yoksa sıvı tedavisi kısıtlı verilmelidir. Hacim genișletici ile kan basıncında yükselme sağlanamaz ise erken dönemde inotropik ajanlar başlanmalıdır (29-31,33,34).

\section{B. İnotropik ve Vazopressör Ajanlar}

Inotropik ve vazopressör ajanlar sistemik hipotansiyonun tedavisinde uzun zamandır kullanılmakla birlikte bu ajanların etkinliğini gösteren az sayıda randomize kontrollü çalışma vardır. Hipotansif prematüre bebeklerde sol ventrikül disfonksiyonu sık olduğu için dopamin veya 
dobutamin gibi inotropik ajanlar kullanılarak miyokardın kasılma gücü artırılabilir, ayrıca inotroplar sistemik vasküler tonusu da etkiler (29,34-36).

\section{Dopamin}

Yenidoğanın hipotansiyon tedavisinde en sık kullanılan farmakolojik ajandır. Noradrenalinin öncülü olan endojen bir katekolamindir. Karmaşık kardiyovasküler etkileri doğrudan dopaminerjik, adrenerjik ve serotonerjik reseptörlerin uyarmasıyla, dolaylı olarak da sempatik sinir uçlarında norepinefrine dönüşmesi ile ortaya çıkar. Düşük dozlarda $(0,5-2 \mu \mathrm{g} / \mathrm{kg} / \mathrm{dk})$ periferik dopamin reseptörlerinin, 2-6 $\mu \mathrm{g} / \mathrm{kg} / \mathrm{dk}$ dozlarında adrenerjik beta $1(\beta 1)$ ve beta 2 ( $\beta 2)$ reseptörlerinin, 6-10 $\mu \mathrm{g} / \mathrm{kg} / \mathrm{dk}$ dozların üzerinde ise adrenerjik alfa $1\left(\alpha_{1}\right)$ ve alfa $2\left(\alpha_{2}\right)$ reseptörlerinin uyarımı belirgin olur $(29,30,34,35,37)$. Prematüre bebeklerde adrenerjik reseptör sistemindeki matürasyon eksikliği ve metabolik temizlenme hızı farklıığından dolayı $\alpha$ reseptör aktivasyonu daha düşük dozlarda gerçekleşir (29). Dopamin, miyokardın kasılmasını ve periferik vasküler direnci artırarak sistemik kan basıncını arttırır (38). Miyokard kasılmasını arttırıc etkisinin \%50'si dolaylı yoldan kardiyak adrenerjik sinir uçlarında depolanmış noradrenalin salınışının uyarılması ile olur, dobutamin de bu etki yoktur $(35,37)$. Dopamin 2-20 $\mu \mathrm{g} / \mathrm{kg} / \mathrm{dk}$ dozunda uygulanabilir, ancak kritik hastalarda adrenerjik reseptör sunumundaki değişiklikler, rölatif adrenal yetmezlik, immatürite ve lokal vazodilatör üretimindeki artışlar sonucu alışılagelmiş dozlarda cevap alınamayabilir (30). Bu durumlarda yüksek doz dopamin diğer sempatomimetik aminlerle birlikte verilebilir. Randomize kontrollü çalışmaların çoğunda çok düşük doğum ağırlıklı bebeklerin \%87-97'sinde dopamin tedavisine $<10 \mu \mathrm{g} / \mathrm{kg} / \mathrm{dk}$ dozunda cevap alındığı gösterilmiştir. Asfiktik zamanında doğmuş bebeklerde 2,5 $\mu \mathrm{g} / \mathrm{kg} / \mathrm{dk}$ dozundaki dopaminin sol ventrikül kasılmasını, sistolik kan basıncını ve renal kan akımını artırdığı gösterilmiş̧tir (39).

Düşük doz dopaminin renal vasküler yapılar üzerine dopaminerjik vazodilatör etkisi net değildir. Seri ve ark. (37) yenidoğanlarda yaptıkları bir çalışmada, dopaminin renal vasküler direnci düşürüp kan akımını \%30, glomerüler filtrasyon hızını ise \%5-20 oranında arttırdığını göstermiştir. Cuevas ve ark. (40) ise respiratuvar distres sendromu olan hipotansif bebeklerde düșük doz (1-2,5 $\mu \mathrm{g} / \mathrm{kg} / \mathrm{dk}$ ) dopaminin renal fonksiyonlar üzerine etkisinin olmadığını bildirmiștir.

Hahn ve ark. (41) yenidoğan domuz yavruları üzerinde yaptığı bir çalışmada hipovoleminin ve dopaminin serebral vaskülarizasyon üzerine etkisini araştırdıkları çalışmalarında serebral perfüzyonu lazer-Doppler ile serebral oksijenizasyonu ise near infrared spektroskopi ile değerlendirmişlervehipovolemininhipotansiyonolmaksızın serebral otoregülasyonu belirgin olarak etkilemediğini, dopamin tedavisinin hacim destek tedavisine göre serebral perfüzyonu daha çok artırdığını, bununla birlikte oksijenizasyonu etkilemediğini bildirmişlerdir.

Yapılan bir metaanalizde dopamin tedavisinin hipotansif premaüre bebeklerde ortalama ve sistolik kan basıncını artırdığı, tek başına hacim genişletici, dobutamin ya da hidrokortizon tedavisine göre daha etkili olduğu, serebral kan akımını arttırdığı bildirilmiştir (42).

Dopaminin pulmoner dolaşım üzerindeki etkisi bilinmemektedir. Pulmoner vasküler direnç üzerine etkisi, pulmoner dopaminerjik reseptörlerin vazodilatasyon yapıcı etkisi ile pulmoner $\alpha$ adrenerjik reseptörlerin vazokonstriksiyon yapıcı etkisi arasındaki dengeye ve mevcut pulmoner hipertansiyona bağlıdır (37). Kesin kanıtlanmamakla birlikte yüksek dozlarda dopaminin pulmoner vazokonstriksiyon yapma potansiyeli olduğu düșünülmektedir. Yenidoğanlarda yüksek dozda dopamin kullanımı, $\alpha$ reseptör aracılı periferik vazokonstriksiyona ve kardiyak atımda azalmaya yol açtığından dolayı önerilmemektedir (34). Dopamin tedavisine dobutamin veya epinefrin gibi başka bir ajanın eklenmesi sık tercih edilir, fakat hangi yaklaşımın daha uygun olacağı konusunda fikir birliği yoktur.

Dopaminin en sık görülen yan etkisi damar dışına kaçma sonrası ağır vazokonstriksiyon ve doku hasarına neden olmasıdır $(29,30,37)$. Tedavide etkilenen alana $\alpha$ reseptör antagonisti olan fentolamin uygulanabilir. Kardiyak aritmi ve gangren diğer nadir komplikasyonlarıdır. Renal yan etkiler arasında hiponatremi ile uzun süreli kullanımda görülen hipofosfatemi ve proksimal renal tübüler asidoz gelişmesi bulunmaktadır (37).

\section{Dobutamin}

Kronotropik ve aritmojenik etkileri minimal olan bir pozitif inotropik ajan olarak geliştirilmiş sentetik bir katekolamindir. Insan ve hayvanlar üzerinde yapılan çalışmalarda bu ilacın miyokard kasılmasını, kardiyak atımı ve kan basıncını arttırdığı, ancak kalp hızını fazla arttırmadığı gösterilmiş̧ir (30). Erişkinlerde kardiyak kasılmayı ve atım hacmini artırmasına karşın kan basıncı üzerine daha az etkisi vardır (43). Dobutaminin, $\beta$ adrenerjik etkisi daha belirgin olup doğrudan inotropik etkisi ile birlikte total periferik vasküler direnci azaltıcı etkisi vardır. $\alpha$ ve $\beta$ adrenerjik reseptörleri birlikte uyarmakla birlikte göreceli olarak $\beta 1$ kardiyoselektif reseptörlere ilgisi daha fazla, periferik $\alpha_{1}$ ve $\alpha_{2}$ reseptörlere ilgisi daha düşüktür (30).

Dopamin ve dobutamin neonatal mortalite ve uzun dönem morbidite üzerine etkileri açısından karşılaştııılığında herhangi bir fark saptanamamıştır. Ancak prematüre bebeklerde hipotansiyon tedavisinde kısa vadede dopamin, dobutaminden daha etkindir 
$(36,42)$. Greenough ve ark. (35), sistolik kan basıncının dopamin ile \%23, dobutamin ile \%11 oranında arttığını göstermişler; ancak orta ve uzun vadeli etkilerde istatistiksel olarak anlamlı bir fark saptamamışlardır. Dobutamin başlıca sorunun miyokard fonksiyon bozukluğu olduğu durumlarda tercih edilmelidir. Septik şokta ise miyokard fonksiyon bozukluğu ve periferik vasküler tonus düşüklüğü bir arada olduğu için dopamin daha iyi bir tercih olabilir (30). Osborn ve ark.'nın (36) düşük sistemik kan akımı olan prematüre bebeklerde dopamin ve dobutamin tedavisini karşılaştırdıkları bir çalışmada, sistemik kan akımının göstergesi olarak superior vena cava akımı ölçülmüş ve dobutaminin dopamine göre bu akımı daha fazla artırdığı saptanmıştır. Prematüre bebeklerde hayatın ilk günlerinde kan basıncı ile sistemik kan akımı arasındaki ilișki düșüktür. $\mathrm{Bu}$ nedenle dopaminin kan basıncını yükseltici etkisi dobutaminden fazla olmasına rağmen, sistemik kan akımını dobutamin daha fazla artırmaktadır (36). Dobutaminin 5-10 $\mu \mathrm{g} / \mathrm{kg} / \mathrm{dk}$ dozunda sol ventrikül fonksiyonları üzerine olumlu etki gösterdiği, 10-20 $\mu \mathrm{g} / \mathrm{kg} /$ dk dozunda ise sistemik kan akımını artırdığı bildirilmiştir. Dobutaminin yenidoğandaki renal, serebral veya pulmoner hemodinamik etkileri konusunda fazla veri yoktur.

\section{Diğer sempatomimetik ajanlar (epinefrin, norepinefrin ve isoproterenol)}

Epinefrin, strese cevap olarak adrenal medulladan salınan ve doğrudan $\alpha$ ve $\beta$ adrenerjik etkiler gösteren endojen bir katekolamindir. Düşük dozlarda $\beta 1$ ve $\beta 2$ etkisi daha belirgindir; miyokard kasılmasını arttıır ve periferik vazodilatasyona neden olur. Yüksek dozlarda $\alpha$ reseptörlerini etkileyerek periferik vazokonstriksiyona neden olur ve sistemik vasküler direnci artırır (26).

Dopaminin yüksek dozlarına rağmen tedaviye dirençli hipotansiyon olgularında epinefrin infüzyonu başlanabilir. Kan basıncını yükseltici etkisi kardiyak kasılmayı artırması sonucudur (44).

Epinefrin hipotansiyon tedavisinde yaygın olarak kullanılmasına rağmen, vazopressör/inotrop etkilerine ve hasta yenidoğan bebeklerdeki klinik sonuçlarına dair az sayıda randomize kontrollü çalışma vardır. Düşük doğum ağırlıklı bebeklerde hipotansiyon tedavisinde epinefrine karşı dopamin tedavisini karşıllaştıran sadece bir çalışma mevcuttur. Bu çalışmada DDA olan bebeklerde erken sistemik hipotansiyon tedavisinde düşük/orta doz epinefrinin düșük/orta doz dopamin kadar etkili olduğu, bununla birlikte geçici yan etkilerinin (taşikardi, hiperglisemi ve laktik asidoz) daha fazla olduğu bildirilmiștir (44). Epinefrin ve diğer yaygın kullanılan inotropik ajanları karşılaştıran daha fazla çalışmaya intiyaç vardır.

Epinefrinin yan etkileri aşırı periferik vazokonstriksiyon sonucu kardiyak atımın azalması ve doku perfüzyonunun bozulması, taşikardi ve damar dışına kaçma hasarıdır (26).

Norepinefrin ise periferik adrenerjik sinir uçlarından salınan bir katekolamindir. Çoğunlukla erişkin ve pediatrik yoğun bakım ünitelerinde; örneğin septik şok gibi, periferik vazodilatasyon ve hipotansiyonun birlikte bulunduğu durumlarda kullanılmaktadır (26).

Isoproterenol, $\beta$ adrenerjik agonisttir. Miyokard kasılmasını artırması yanında taşikardi yapıcı etkisi belirgindir; ayrıca periferik vazodilatasyon ve hipotansiyon yapabilir (30).

\section{Kortikosteroidler}

Kritik hastalığı ve inotropik ajanlara rağmen dirençli hipotansiyonu olan hastalarda kısa süreli steroid tedavisi kardiyovasküler durumu stabilize edebilir $(30,33)$. Ağır hasta prematürelerde hipotalamo-pituiter-adrenal aks olgunlaşmamıştır ve kısmi adrenal yetmezlik vardır; kritik hastalık durumunda bile endojen steroid üretimi yeterli oranda arttırılamaz (45). Scott ve ark. (45), plazma kortizol düzeyi ile gestasyon yaş arasında ters orantılı bir ilişki saptamış, özellikle inotropik desteği gerektiren hipotansif bebeklerde kortizol düzeyinin çok düşük olduğunu bildirmişlerdir.

Kortikosteroidlerin kardiyovasküler sistem üzerindeki etkileri mineralokortikoid etkilerine bağlı su ve sodyum tutulumu sonucu tansiyonu yükseltmesi ve vazoaktif maddelere karşı olan vasküler reaktiviteyi ve miyokardiyal kasıımayı arttırmasıdır. Kortizol düşüklüğünde norepinefrin ve anjiotensin Il'ye yetersiz cevap gözlenir (33).

Moise ve ark. (46) yaptıkları bir çalışmada, ÇDDA olan bebeklerde antenatal steroid kullanımının kan basıncının desteklenmesine olan gereksinimi azalttığını göstermişsir. Helbock ve ark. (47), ÇDDA olan bebeklerde hacim genişletici, dopamin ve dobutamin desteğine rağmen dirençli seyreden hipotansiyonun tedavisinde hidrokortizonun kan basıncını arttırdığını bildirmiştir. Yapılan bir metaanalizde hidrokortizon tedavisinin prematüre bebeklerde vazopressör ilaç gereksinimini azalttığı ve kan basıncını normal seviyeye yükselttiği bildirilmiştir. Bununla birlikte klinik faydasının tartışmalı olduğu, uzun dönemde yan etkilerinin olabileceği belirtilmiştir (48). Düşük serum kortizol düzeyi olan hipotansif bebeklerde hidrokortizon tedavisi faydalı olabilir. Bu nedenle ÇDDA olan bebeklerde hidrokortizon tedavisi planlandığında bazal serum kortizol düzeyi bakılması düşünülebilir (15).

Sonuç olarak, rutin ve profilaktik olarak sistemik kortikosteroid kullanımı potansiyel yan etkileri nedeniyle önerilmemektedir. Ancak dirençli hipotansiyon ve hayatı tehdit eden durumlarda hacim genişletici ve vazopressör/ inotropik tedaviye yardımc bir ajan olarak kullanılabilir (49). 


\section{Diğer ajanlar}

\section{Dopeksamin}

Dopaminerjik ve $\beta_{2}$ adrenerjik özellikleri olan sentetik bir katekolamindir. Hepatik, splanknik ve renal vasküler direnci azaltarak bu organlara kan akımını arttırı. Pediatrik yoğun bakımda dopeksamin kullanımı ile ilgili az sayıda çalışma vardır. On yedi ÇDDA olan prematüre bebekte yapılan bir çalışmada, dopeksaminin kan basıncını ve idrar Çıkışını artıırdığı gösterilmiştir (50).

\section{Milrinon}

Kardiyak kasılmadaki artıșı intrasellüler döngüsel AMP (cAMP) düzeyini arttırarak sağlayan bir inotropik ajandır; bu etkisini cAMP'yi yıkan fosfodiesteraz tip III enzimini inhibe ederek yapar (51). Yenidoğan döneminde bu ilacın etkinliği ve güvenilirliğine ilişkin yeterli bilgi yoktur.

\section{Metilen mavisi}

Yenidoğanda septikşokun neden olduğu hipotansiyonda guanilat siklaz aktivasyonu söz konusudur. Guanilat siklazı inhibe eden metilen mavisi septik şok ve dirençli hipotansiyonu olan yenidoğan bebeklerde kullanılmıştır (52). Fakat metilen mavisinin yenidoğan hipotansiyonunda etkinliğini değerlendiren kontrollü çalışmalar yoktur.

\section{Arjinin vazopressin (AVP)}

AVP, 1997'den bu yana vazodilatasyonla seyreden şok tablosundaki erişkin hastalarda vazopressör ajan olarak kullanılmaktadır. Yapılan bir çalışmada düşük doz vazopressin infüzyonunun sistolik ve diastolik kan basıncını arttırdığı, yüksek doz epinefrin infüzyonuna ve/veya kortikosteroid tedavisine dirençli hipotansiyonu bulunan CDDA olan bebeklerde kullanılabileceği bildirilmiștir (53). Ancak prematüre bebeklerde vazopressin infüzyon tedavisinin etkinliği ve güvenliği konusunda çok daha fazla çalışmaya intiyaç vardır.

Yenidoğanda hipotansiyon tedavisi için önerilen bir algoritma Şekil 2'de sunulmuştur (26).

Sonuç olarak, hipotansiyon tanımında sağlıklı yenidoğan bebeklerden elde edilen referans değerleri esas alınır. Hipotansiyonun tanı ve tedavisi yenidoğanda gelişebilecek olan PVL, VIK ve serebral iskemik hasar gibi komplikasyonlardan kaçınmak için önemlidir. Hacim genişleticiler, vazoaktif tedavi ve kortikosteroidler hipotansiyon tedavisinin değişik kombinasyonları arasında yer alır. Dopamin prematüre bebeklerde görülen hipotansiyonun tedavisinde hacim genişletici desteğinden daha etkilidir. Dobutamin ile karşılaştııılığında dopamin hipotansiyon tedavisinde daha etkilidir. Kortikosteroidler ve epinefrin dirençli hipotansiyon tedavisinde kullanılabilir.

\section{Kaynaklar}

1. Watkins AM, West CR, Cooke RW. Blood pressure and cerebral haemorrhage and ischaemia in very low birthweight infants. Early Hum Dev 1989;19:103-10.
2. Miall-Allen VM, de Vries LS, Whitelaw AG. Mean arterial blood pressure and neonatal cerebral lesions. Arch Dis Child 1987;62:1068-9.

3. Pellicer A, Bravo MC, Madero R, Salas S, Quero J, Cabañas F. Early systemic hypotension and vasopressor support in low birth weight infants: impact on neurodevelopment. Pediatrics 2009;123:1369-76.

4. Öztürk MA, Büyükayhan D. Yenidoğanda hipotansiyon. Bakırköy Tıp Dergisi 2011;7:1-5.

5. Al-Aweel I, Pursley DM, Rubin LP, Shah B, Weisberger S, Richardson DK. Variations in prevalence of hypotension, hypertension, and vasopressor use in NICUs. J Perinatol 2001;21:272-8.

6. Jones JG, Smith SL. Shock in the critically ill neonate. J Perinat Neonatal Nurs 2009;23:346-54.

7. Fanaroff JM, Wilson-Costello DE, Newman NS, Montpetite MM, Fanaroff AA. Treated hypotension is associated with neonatal morbidity and hearing loss in extremely low birth weight infants. Pediatrics 2006;117:1131-5.

8. Fanaroff JM, Fanaroff AA. Blood pressure disorders in the neonate: hypotension and hypertension. Semin Fetal Neonatal Med 2006;11:174-81.

9. Seril. Cardiovascular, renal, and endocrine actions of dopamine in neonates and children. J Pediatr 1995;126:333-44.

10. Seri I. Circulatory support of the sick preterm infant.Semin Neonatol 2001;6:85-95.

11. Perkin RM, Levin DL. Shock in the pediatric patient. Part I. J Pediatr 1982;101:163-9.

12. Nuntnarumit P, Yang W, Bada-Ellzey HS. Blood pressure measurements in the newborn. Clin Perinatol 1999;26:98196.

13. Kent AL, Kecskes Z, Shadbolt B, Falk MC. Blood pressure in the first year of life in healthy infants born at term. Pediatr Nephrol 2007;22:1743-9.

14. Kent AL, Meskell S, Falk MC, Shadbolt B. Normative blood pressure data in non-ventilated premature neonates from 2836 weeks gestation. Pediatr Nephrol 2009;24:141-6.

15. Vargo L, Seri I. New NANN Practice Guideline: the management of hypotension in the very-low-birth-weight infant. Adv Neonatal Care 2011;11:272-8.

16. Kluckow M, Evans N. Low systemic blood flow in the preterm infant. Semin Neonatol 2001;6:75-84.

17. Evans N. Assessment and support of the preterm circulation. Early Hum Dev 2006;82:803-10.

18. Kluckow M, Evans N. Superior vena cava flow in newborn infants: a novel marker of systemic blood flow Arch Dis Child Fetal Neonatal Ed 2000;82:182-7.

19. Noori S, Stavroudis TA, Seri I. Systemic and cerebral hemodynamics during the transitional period after premature birth. Clin Perinatol 2009;36:723-36.

20. Kehrer M, Blumenstock G, Ehehalt S, Goelz R, Poets C, Schöning M. Development of cerebral blood flow volume in preterm neonates during the first two weeks of life. Pediatr Res 2005; $58: 927-30$

21. Tyszczuk L, Meek J, Elwell C, Wyatt JS. Cerebral blood flow is independent of mean arterial blood pressure in preterm infants undergoing intensive care. Pediatrics 1998;102:337-41.

22. Goldstein RF, Thompson RJ Jr, Oehler JM, Brazy JE. Influence of acidosis, hypoxemia, and hypotension on neurodevelopmental outcome in very low birth weight infants. Pediatrics 1995;95:238-43. 
23. Mattia FR, deRegnier RA. Chronic physiologic instability is associated with neurodevelopmental morbidity at one and two years in extremely premature infants. Pediatrics 1998;102:35.

24. Dempsey EM, Barrington KJ. Treating hypotension in the preterm infant: when and with what: a critical and systematic review J Perinatol 2007;27:469-78.

25. Ahn SY, Kim ES, Kim JK, Shin JH, Sung SI, Jung JM, Chang YS, Park WS. Permissive hypotension in extremely low birth weight infants ( $\leq 1000 \mathrm{gm})$. Yonsei Med J 2012;53:765-71.

26. Subhedar NV. Treatment of hypotension in newborns. Semin Neonatol 2003;8:413-23.

27. Dempsey EM, Barrington KJ. Treating hypotension in the preterm infant: when and with what: a critical and systematic review. J Perinatol 2007;27:469-78.

28. Pladys P, Wodey E, Beuchée A, Branger B, Betremieux P. Left ventricle output and mean arterial blood pressure in preterm infants during the 1st day of life. Eur J Pediatr 1999;158:81724.

29. Barrington KJ. Circulatory effects of dopamine in neonates. J Pediatr 1995;127:843-4.

30. Seri I, Evans J. Controversies in the diagnosis and management of hypotension in the newborn infant. Curr Opin Pediatr 2001;13:116-23.

31. So KW, Fok TF, Ng PC, Wong WW, Cheung KL. Randomised controlled trial of colloid or crystalloid in hypotensive preterm infants. Arch Dis Child Fetal Neonatal Ed 1997;76:43-6.

32. Sasidharan P. Role of corticosteroids in neonatal blood pressure homeostasis. Clin Perinatol 1998;25:723-40.

33. Göksedef D, Yalvaç EŞD, Ömeroğlu SN. Inotropik Ilaçların Klinik Kullanımı. Turkiye Klinikleri J Cardiovasc Surg-Special Topics 2012;4:92-102.

34. Rozé JC, Tohier C, Maingueneau C, Lefèvre M, Mouzard A. Response to dobutamine and dopamine in the hypotensive very preterm infant. Arch Dis Child 1993;69:59-63.

35. Greenough A, Emery EF. Randomized trial comparing dopamine and dobutamine in preterm infants. Eur $\mathrm{J}$ Pediatr 1993;152:925-7.

36. Osborn D, Evans N, Kluckow M. Randomized trial of dobutamine versus dopamine in preterm infants with low systemic blood flow. J Pediatr 2002;140:183-91.

37. Seri I. Cardiovascular, renal, and endocrine actions of dopamine in neonates and children. J Pediatr 1995;126:333-44.

38. Aşılıoğlu N, Demirkol D. Vazoaktif Ilaçlar. Turkiye Klinikleri J Pediatr Sci 2011;7:96-103.

39. DiSessa TG, Leitner M, Ti CC, Gluck L, Coen R, Friedman WF. The cardiovascular effects of dopamine in the severely asphyxiated neonate. J Pediatr 1981;99:772-6.
40. Cuevas L, Yeh TF, John EG, Cuevas D, Plides RS. The effect of low-dose dopamine infusion on cardiopulmonary and renal status in premature newborns with respiratory distress syndrome. Am J Dis Child 1991;145:799-803.

41. Hahn GH, Heiring C, Pryds 0, Greisen G. Cerebral vascular effects of hypovolemia and dopamine infusions: a study in newborn piglets. Acta Paediatr 2012;101:736-42.

42. Sassano-Higgins S, Friedlich P, Seri I. A meta-analysis of dopamine use in hypotensive preterm infants: blood pressure and cerebral hemodynamics. J Perinatol 2011;31:647-55.

43. Enrico C, Kanoore Edul VS, Vazquez AR, Pein MC, Pérez de la Hoz RA, Ince C, et al. Systemic and microcirculatory effects of dobutamine in patients with septic shock. J Crit Care 2012;27:630-8.

44. Valverde E, Pellicer A, Madero R, Elorza D, Quero J, Cabañas F. Dopamine versus epinephrine for cardiovascular support in low birth weight infants: analysis of systemic effects and neonatal clinical outcomes. Pediatrics 2006;117:1213-22.

45. Scott SM, Watterberg KL. Effect of gestational age, postnatal age, and illness on plasma cortisol concentrations in premature infants. Pediatr Res 1995;37:112-6.

46. Moïse AA, Wearden ME, Kozinetz CA, Gest AL, Welty SE, Hansen TN. Antenatal steroids are associated with less need for blood pressure support in extremely premature infants. Pediatrics 1995;95:845-50.

47. Helbock HJ, Insoft RM, Conte FA. Glucocorticoid-responsive hypotension in extremely low birth weight newborns. Pediatrics 1993:92:715-7.

48. Higgins S, Friedlich P, Seri I. Hydrocortisone for hypotension and vasopressor dependence in preterm neonates: a metaanalysis. J Perinatol 2010;30:373-8.

49. Ibrahim H, Sinha IP, Subhedar NV. Corticosteroids for treating hypotension in preterm infants. Cochrane Database Syst Rev 2011;7: CD003662. doi: 10.1002/14651858.

50. Kawczynski P, Piotrowski A. Circulatory and diuretic effects of dopexamine infusion in low-birth-weight infants with respiratory failure. Intensive Care Med 1996;22:65-70.

51. Packer M, Carver JR, Rodeheffer RJ, Ivanhoe RJ, DiBianco R, Zeldis SM, et al. Effect of oral milrinone on mortality in severe chronic heart failure. The PROMISE Study Research Group. N Engl J Med 1991;325:1468-75.

52. Driscoll W, Thurin S, Carrion V, Steinhorn RH, Morin FC 3rd. Effect of methylene blue on refractory neonatal hypotension. J Pediatr 1996;129:904-8.

53. Ikegami $H$, Funato $M$, Tamai $H$, Wada $H$, Nabetani M, Nishihara M. Low-dose vasopressin infusion therapy for refractory hypotension in ELBW infants. Pediatr Int 2010;52:368-73. 